Metodički obzori 6(2011)1

Original scientific article

UDK: 159.9.072:371.13

Received: 18. 8. 2010.

\title{
APPLICATION OF MANN-WHITNEY U TEST IN RESEARCH OF PROFESSIONAL TRAINING OF PRIMARY SCHOOL TEACHERS
}

\author{
Zivorad M. Milenovic, MSc \\ Faculty of Education, Leposavic (Serbia) \\ e-mail: zivorad.milenovic @ pr.ac.rs
}

\begin{abstract}
A b s tract
This paper presents the Mann-Whitney U Test statistical technique used in statistics to examine differences between two independent groups on a continuous scale. This test is a non-parametric alternative to the t-test for independent samples. Unlike the t-test which compares mean values between two groups, Mann-Whitney $\mathrm{U}$ Test compares their median. In researches of the professional development of teachers of primary schools, the most commonly used criterion variables were gender (male, female), education (college, university), occupation (class teacher/ subject teacher) and school environment (urban, rural). It is noticeable that these variables are characterized by the existence of two independent groups, which is one of the preconditions for the implementation of the Mann-Whitney U Test. In order to better understand the Mann-Whitney U Test statistical technique, it is presented in the example of practical application within the statistical program SPSS. Its application includes data processing, calculating the median of each group, interpretation of research results, and establishment of the amount of influence among the crossed variables.
\end{abstract}

Key words: statistical techniques, Mann-Whitney U Test, teacher, elementary school, professional development

\section{Introductory explanation}

Mann-Whitney $\mathrm{U}$ test is a non-parametric statistical technique. It is used to analyze differences between the medians of two data sets. It can be used in place of a t-test for independent samples in cases where the values within the sample do not follow the normal or t-distribution but also when the distribution of values is unknown. In order for the Mann-Whitney $U$ test to be applied, values need to be measurable on an ordinary scale and comparable in size. The fact that all values are compared makes it distinct from the t-test, which compares the sample means. The Mann-Whitney $\mathrm{U}$ is also used to test the null hypothesis, subject to both samples coming from the same basic set or having the same median value. 
In the professional development of primary school teachers, counsellors, psychologists and andragogists pay special attention to their preparation for education in primary school, in particular, to their pedagogical-psychological and didactic competence (Bim-Bad (ed.), 2002). This primarily refers to the expertise of teachers to bring up and educate within the full meaning of these terms, not only to apply the knowledge in the field. During their schooling, a considerable number of teachers do not receive sufficient knowledge required for education at primary school. Consequently, when working with their student, they s do not apply forms, methods and tools which could facilitate the achievement of expected outcomes of teaching and each student's personal maximum depending on his abilities, preferences and interests.

Professional development of primary school teachers is approached from two points of view. One point of view "...assumes that a teacher completes systematic studies by obtaining a diploma, and the other that a teacher's systematic learning (mastering of formal preparation programs for education in primary school during the studies) represents a good start for further professional development" (Mižerikov, 2004). The theoretical concept of teachers' professional development for education in elementary school includes methodological and professionalmethodical training of teachers, but also their traditional professional education and training. Hence the position of lifelong learning teacher training for education in primary schools is in accordance with the needs of the teaching profession.

In the studies of professional development of teachers of primary schools the most commonly used criterion variables were gender (male, female), education (college, university), occupation (class teacher, subject teacher) and school environment (urban, rural). Research issues which may be asked in the professional development of teachers comprise: do male and female teachers with college and university education, class and subject teachers and teachers employed in primary schools in urban and rural areas differ in the level of understanding of the importance and need of their professional development for education in primary school. Answers to these questions can be reached effectively using the MannWhitney U test. In order to understand better the Mann-Whitney U Test statistical technique, it is presented on the example of practical application within the statistical program SPSS, followed by discussion and analysis of research results.

\section{Procedure for processing data obtained by Mann-Whitney U test}

For the Mann-Whitney $\mathrm{U}$ test to be applied, a number of assumptions need to be met. The most important are: (a) coincidence of the sample and (b) independence of observations. Independence of observations implies "...that each observation can be counted only once ..." (Pallant, 2009: 214). This, in other words, means that the observations may not appear in multiple categories or groups and that data referring to one subject cannot affect the data of others. The above criterion also applies to 
other non-parametric techniques that have been studied by numerous authors (Gravertter and Wallnau, 2004, Peat, 2001; Pett et. all, 2003). Exceptions are the Wilcoxon rank test and Friedman test where the same subjects can be tested repeatedly and in different circumstances.

The Mann-Whitney U test in the SPSS statistical program is performed in two parts. The first part represents the main part of the Mann-Whitney U test, and the second part the calculation of the median of each group. When the database to be processed is activated, the Analyze menu opens first. Then items Nonparametric Tests and 2 Independent Samples are selected. After that, the continuous dependent variable on the professional development of teachers is shifted in the field Test Variable List, and, depending on the profession of teachers (class teacher / subject teacher), into the field Grouping Variable. In order to encrypt the values of the variable it is necessary to select the field Define Groups. For group 1, in the box next to it number 1 is entered, and for Group 2, No. 2. After that the command Continue is selected and in the section Test Type the field Mann-Whitney U test is confirmed. In the end, the option Options is selected, Descriptives is checked for and the commands Continue and OK are entered.

The second part comprises the procedure of calculating the median of each group. It begins by opening the menu Analyze and selecting Compare Means and Means. After that, the dependent variable is shifted in the field Dependent List, and the criterion independent variable on the profession of the teacher in the Independent List box. The option Options is then selected. On this occasion rotation is performed in the way that Median switches from the Statistics field in the field Cell Statistics and Mean and Standard Deviation switch from the field Cell Statistics to the Statistics field. In the end the commands Continue and OK are given.

\section{Interpretation of results - discussion and analysis}

Test results of a study carried out on a sample of 108 primary school teachers in the district of Kosovska Mitrovica, in April-June 2010, were used to describe the interpretation of research results using the Mann-Whitney $U$ test. As the sample included more than 30 subjects the z-approximation was calculated. Data presented in Tables Ranks, Test Statistics (a) and Report were to interpret the results of the research

Table 1 presents data on the calculated $\mathrm{z}$-values and the approximately calculated statistical significance of differences between the crossed variables. In this example, the $\mathrm{z}$-value was -1.018 . The amount of its probability that something happened by accident is not equal to or less than 0.05 . The same was shown by the approximately calculated statistical significance of differences (p-309). The research results, therefore, showed no statistically significant differences in the professional development of teachers of primary schools according to their occupation (class teacher / subject teacher). 
Table 1 Professional development of primary school teachers (Test Statistics (a))

\begin{tabular}{|l|r|}
\hline & $\begin{array}{r}\text { Professional } \\
\text { development }\end{array}$ \\
\hline Mann-Whitney U & 1302,000 \\
Wilcoxon W & 2787,000 \\
$\mathrm{Z}$ & $-1,018$ \\
Asymp. Sig. (2- &, 309 \\
tailed) & \\
\hline
\end{tabular}

a Grouping Variable: Interest

Table 2 Professional development of primary school teachers (Ranks)

\begin{tabular}{|l|r|c|c|}
\hline Interest & N & $\begin{array}{c}\text { Mean } \\
\text { Rank }\end{array}$ & $\begin{array}{c}\text { Sum of } \\
\text { Ranks }\end{array}$ \\
\hline $\begin{array}{l}\text { Professional development } \\
\text { class teacher }\end{array}$ & 44 & 51,61 & 2787,00 \\
\hline subject teachers & 64 & 57,39 & 3099,00 \\
\hline Total & 108 & & \\
\hline
\end{tabular}

As there were no statistically significant differences between crossed variables, there was no need to analyze the data shown in Table 2. This table (column Mean Rank) shows which continuous variable was higher on average. It is, however, done only where determined statistically significant difference between the crossed variables is determined. However, it is recommended that the results show the median of each group.

Table 3 Professional development of primary school teachers (Report)

\begin{tabular}{|l|r|c|}
\hline Interest & \multicolumn{1}{|c|}{$\mathrm{N}$} & Median \\
\hline class teacher & 44 & 25,0000 \\
\hline subject teachers & 64 & 45,0000 \\
\hline Total & 108 & 35,0000 \\
\hline
\end{tabular}

Data on the medians of the groups are shown in Table 3. They show that on average continuous variables were higher in subject teachers than in class teachers. The size of the influence of the ( $r$ ) profession of primary school teachers in their professional development for education in primary school was not calculated in the statistical program SPSS. The form used for its calculation is $\mathrm{r}=\mathrm{z}$ / square root of $\mathrm{N}$ 
(total number of cases) (Watkins, 2000; Tabachnick and Fidell, 2007; Suzic, 2007; Sheepskin and Suzic, 2010: 132-133). In this case the values were as follows: z-(1.018 ) and $\mathrm{N}-108$. By applying the above form, the calculated value of $r$ was -0.11 . By application of the Cohen criterion (1988) this is considered small effect $(0.1$ small effect, 0.3 - medium effect, and 0.5 - big effect).

\section{Instead of conclusion}

This paper describes the use of the Mann-Whitney $U$ test, as an alternative to the t-test. Unlike the t-test which compares the mean values of two groups, the Mann-Whitney U test compares their medians. This statistical technique examines the differences between two independent groups on a continuous scale. It is therefore considered a specific statistical technique that is significantly different from other nonparametric tests, primarily from the Wilcoxon rank test and Friedman test. The work is intended for all who are deeply engaged in empirical research, especially using the nonparametric tests. In previous works a large disagreement with the application of this statistical technique was present, particularly in the interpretation of research results and especially in understanding of the Cohen criterion. This primarily referred to the psychologists, who considered the lower limit of the criterion being of 0.00 instead of 0.01 . This approach made this already complex statistical technique even more complex. Consequently, its verification, notably in the studies of younger and often under-experienced and under-qualified authors guided by these parameters, was mainly difficult and / or unattainable. In addition to theoretical considerations of the Mann-Whitney U test, a practical MannWhitney U test procedure conducted by means of the statistical program SPSS was presented. Also, an example of interpretation, discussion and analysis of research results obtained by the Mann-Whitney $U$ test was given. The example of a discussion of the results obtained Mann-Whitney $U$ test was shown using the results obtained in this research and based on the principles and adopted value parameters being applied for discussion and analysis of research results obtained by the MannWhitney U test.

\section{References}

1. Bim-Bad, B.M. (red.) (2002). Pedagogičekiй enciklopedičeskiй slovarь. Moskva: Naučnoe izdatelıstvo „Bolьšaя rossiйskaя эnciklopediя".

2. Cohen, J.W. (1988). Statistical power analysis for the behavioral sciences (2nd edn). New Jersey: Lawrence Erlbaum Associates.

3. Gravetter, F.J. \& Wallnau, L.B. (2004). Statistics for the behavioral sciences (6th edn.). Belmont: Wadsworth. 
4. Kožuh, B. i Suzić, N. (2010). Obrada podataka u istraživanjima. Banjluka: Filozofski fakultet Univerziteta u Banjaluci.

5. Mižerikov, V.A. (2004). Slovarb-spravočnik po pedagogike. Moskva: Tvorčeskiй centr.

6. Pallant, J. (2009). SPSS Survival Manual. New York: Allen \& Unwin.

7. Peat, J.(2001). Health science research: A handbook of quantitative methods. Sydney: Allen \& Unwin.

8. Pett, M.A., Lackey, N.R. \& Sullivan, J.J. (2003). Making sense of factor analisys: the use of factor analisys for instrument development in health care research. Thousand Oake: Sage.

9. Suzić, N. (2007). Primenjena pedagoška metodologija. Banjaluka:HBS.

10. Tabachnick, B.G. \& Fidell, L.S. (2007). Using multivariate statistics. Boston: Pearson Education.

11. Watkins, M.W. (2000). Monte Carlo PCA for paralell analysis (computer softver). State College, PA: Ed \& Psych Associates.

Metodički obzori 6(2011)1

Izvorni znanstveni rad

UDK: $159.9 .072: 371.13$

Primljeno: 18. 8. 2010.

\section{PRIMENA MAN-VITNIJEVOG U TESTA U ISTRAŽIVANJIMA PROFESIONALNOG USAVRŠAVANJA NASTAVNIKA OSNOVNE ŠKOLE}

Mr. sc. Živorad M. Milenović Učiteljski fakultet, Leposavić, Srbija e-mail: zivorad.milenovic@ @ pr.ac.rs

$S \boldsymbol{a} \check{z} \boldsymbol{e} \boldsymbol{t} \boldsymbol{a} \boldsymbol{k}$

U radu je prikazana statistička tehnika Man-Vitnijev $U$ test kojim se u statistici ispituju razlike između dve nezavisne grupe na neprekidnoj skali. Ovaj test je neparametrijska alternativa t-testu nezavisnih uzoraka. Za razliku od t-testa koji poredi srednje vrednosti dveju grupa, Man-Vitnijev $U$ test poredi njihove medijane. U istraživanjima profesionalnog usavršavanja nastavnika osnovne škole, najčešće korišćene kriterijumske varijable su pol (muški, ženski), školska sprema (viša, visoka), zanimanje (nastavnik razredne/predmetne nastave) i područje škole (gradsko, seosko). Uočljivo je da navedene varijable karakteriše postojanje dve nezavisne grupe, što je jedan od preduslova za sprovođenje Man-Vitnijevog $U$ testa. Da bi se lakše shvatila i razumela, statistička tehnika Man-Vitnijev U test, prikazana je na primeru praktične primene u statističkom programu SPSS. Njena primena podrazumeva obradu podataka, izračunavanje medijana svake grupe, tumačenje rezultata istraživanja, i utvrđivanje veličine uticaja među ukrštanim varijablama. 
Ključne reči: statistička tehnika, Man-Vitnijev U test, nastavnik, osnovna škola, profesionalno usavršavanje 